\title{
Commentary: How old is too old for aortic arch surgery?
}

\author{
Christopher K. Mehta, MD, and S. Chris Malaisrie, MD
}

From the Division of Cardiac Surgery, Department of Surgery, Northwestern University Feinberg School of Medicine and Northwestern Memorial Hospital, Chicago, Ill.

Disclosures: Authors have nothing to disclose with regard to commercial support.

Received for publication Nov 27, 2018; accepted for publication Nov 28, 2018; available ahead of print Jan 18, 2019.

Address for reprints: S. Chris Malaisrie, MD, Division of Cardiac Surgery, Northwestern University Feinberg School of Medicine, Northwestern Memorial Hospital, 201 E Huron St, Suite 11-140, Chicago, IL 60611 (E-mail: chris.malaisrie@nm.org).

J Thorac Cardiovasc Surg 2019;158:982-3

$0022-5223 / \$ 36.00$

Copyright (c) 2018 by The American Association for Thoracic Surgery

https://doi.org/10.1016/j.jtcvs.2018.11.114

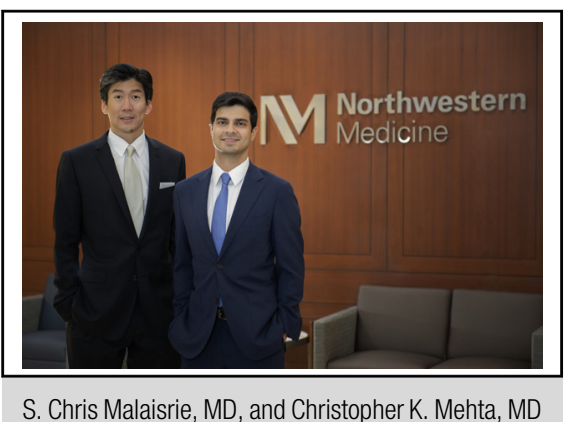

\section{Central Message}

Aortic arch surgery in elderly patients carries significant risk of morbidity and mortality. Novel endovascular therapies may be better for quality of life and mortality in elderly patients.

See Article page 973. found to be an independent predictor of mortality. Older age also conferred an additional risk of prolonged ventilatory failure and renal insufficiency. Although the authors report excellent outcomes, each decade added increased operative mortality, with octogenarians having an operative mortality of $16.9 \%$. The authors should be congratulated for these excellent outcomes in elective aortic arch surgery. As they point out, these data will serve as an important benchmark of surgical repair against which the outcomes of emerging endovascular therapies will be compared.

An important distinction must be made between a hemiarch operation versus total arch replacement. Although hemiarch repair increases perfusion time and includes a brief period of circulatory arrest time, in our experience it does not affect safety or operative mortality. ${ }^{2}$ A total arch replacement, however, is a more complex operation that requires longer cardiopulmonary bypass time, longer circulatory arrest time, and cerebral protection adjuncts. ${ }^{3}$ Indeed, in this study total arch as compared with hemiarch was found to be an independent risk factor for operative mortality.

Advancing age is known to be an independent predictor of mortality across the spectrum of aortic arch surgical interventions. ${ }^{4}$ A number of risk-stratification models aim to determine a patient's fitness for surgery by focusing on physiological age instead of chronological age. ${ }^{5}$ Specifically, markers of frailty and comorbidity profile can predict operative mortality in aortic arch surgery. Postoperative quality of life, however, plays an important role in determining the optimal treatment of complex aortic arch pathologies. Among patients $>75$ years old in this study, $50.4 \%$ of patients were discharged home, whereas $49.6 \%$ were discharged to a nursing home, rehabilitation

center, or long-term care facility. Comparably, among patients aged 50 to 74 years old, $81.5 \%$ were discharged home whereas only $18.5 \%$ were sent to another care facility. This difference underscores the high toll that open surgical repair plays on the quality of life of elderly patients.

As total endovascular or hybrid therapies evolve to treat aortic arch pathologies, patients $>75$ years old will likely be better served with these less-invasive interventions, particularly in quality of life. Similar to the transcatheter aortic valve replacement experience in high-risk and prohibitive risk elderly patients, endovascular therapies will undoubtedly offer less perioperative morbidity, decrease hospital lengths of stay, and obviate the adverse effects of cardiopulmonary bypass and hypothermic circulatory arrest. A number of thoracic endovascular aortic repair aortic arch trials are currently underway to assess their feasibility in treating arch pathologies. ${ }^{6-10} \mathrm{We}$ are not there yet, but as transcatheter therapies evolve to treat aortic arch aneurysms and dissections, it will become harder to justify open surgical repair in lieu of endovascular treatment in elderly patients.

\footnotetext{
References

1. Preventza O, Price MD, Amarasekara HS, Ozozco-Sevilla V, Chatterjee S, Zhang Q, et al. In the endovascular era, is elective open aortic arch surgery in elderly patients still justified? J Thorac Cardiovasc Surg. 2019;158:973-9.

2. Malaisrie SC, Duncan BF, Mehta CK, Badiwala MV, Rinewalt D, Kruse J, et al. The addition of hemiarch replacement to aortic root surgery does not affect safety. J Thorac Cardiovasc Surg. 2015;150:118-24.e2.
} 
3. Poon SS, Theologou T, Harrington D, Kuduvalli M, Oo A, Field M. Hemiarch versus total aortic arch replacement in acute type A dissection: a systematic review and meta-analysis. Ann Cardiothorac Surg. 2016;5:156-73.

4. Patel HJ, Nguyen C, Diener AC, Passow MC, Salata D, Deeb GM. Open arch reconstruction in the endovascular era: analysis of 721 patients over 17 years. J Thorac Cardiovasc Surg. 2011;141:1417-23.

5. Sepehri A, Beggs T, Hassan A, Rigatto C, Shaw-Daigle C, Tangri N. The impact of frailty on outcomes after cardiac surgery: a systematic review. J Thorac Cardiovasc Surg. 2014;148:3110-7.

6. W.L. Gore and Associates. Evaluation of the GORE® TAG® Thoracic Branch Endoprosthesis (TBE Device) in the Treatment of Lesions of the Aortic Arch and Descending Thoracic Aorta (Zone 0/1). 2020. Available at: https://clinicaltrials.gov/ct2/show/NCT02777528. Accessed November 26, 2018.
7. University Hospital, Toulousem, and Medtronic Vascular. Evaluation of the Valiant Mona LSA Thoracic Stent Graft System in Thoracic Aortic Aneurysms and Chronic Dissections. 2021. Available at: https://clinicaltrials.gov/ct2/ show/NCT03738124. Accessed November 26, 2018.

8. Bolton Medical. Early Feasibility Study of the RelayBranch Thoracic Stent-Graft System. 2019. Available at: https://clinicaltrials.gov/ct2/show/NCT03214601. Accessed November 26, 2018.

9. Haulon S, Greenberg RK, Spear R, Eagleton M, Abraham C, Lioupis C, et al. Global experience with an inner branched arch endograft. J Thorac Cardiovasc Surg. 2014;148:1709-16.

10. Universitätsklinikum Düsseldorf and Askelpios Klinikum, Endospan Ltd, The Single Branch NEXUS ${ }^{\mathrm{TM}}$ Clinical Study (NexusSB), 2019. Avaliable at https://clinicaltrials.gov/ct2/show/NCT03208504. Accessed December 31, 2018

Access to The Journal of Thoracic and Cardiovascular Surgery Online is reserved for print subscribers!

Full-text access to The Journal of Thoracic and Cardiovascular Surgery Online is available for all print subscribers. To activate your individual online subscription, please visit The Journal of Thoracic and Cardiovascular Surgery Online, point your browser to http://www.mosby.com/jtcvs, follow the prompts to activate your online access, and follow the instructions. To activate your account, you will need your subscriber account number, which you can find on your mailing label (note: the number of digits in your subscriber account number varies from 6 to 10 ). See the example below in which the subscriber account number has been circled:

\section{Sample mailing label}

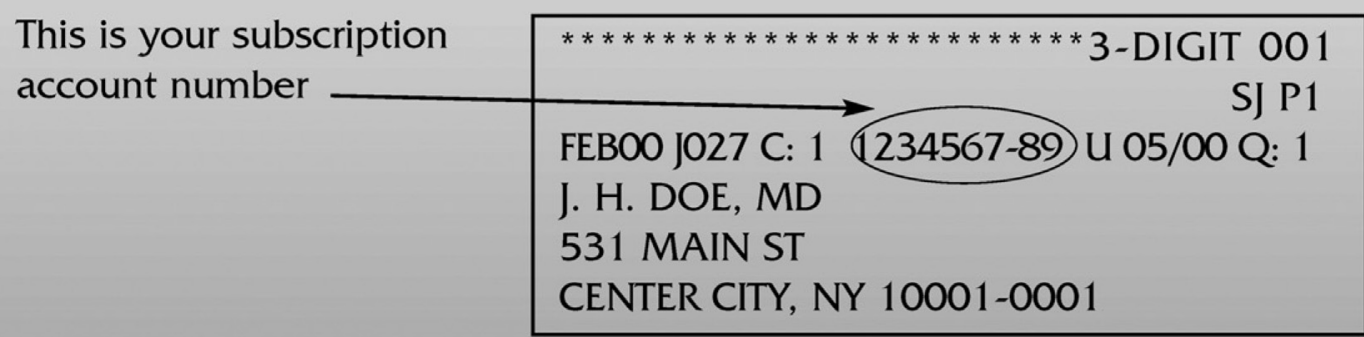

Personal subscriptions to The Journal of Thoracic and Cardiovascular Surgery Online are for individual use only and may not be transferred. Use of The Journal of Thoracic and Cardiovascular Surgery Online is subject to agreement to the terms and conditions as indicated online. 